\title{
REFLECTION
}

\section{You Can't Hide the Bridges}

Lauren S. Hugbes, MD, MPH',

${ }^{1}$ Robert Wood Johnson Foundation Clinical Scholars Program

${ }^{2}$ Department of Family Medicine, University of Michigan, Ann Arbor, Michigan
Conflicts of interest: author reports none.

\section{CORRESPONDING AUTHOR}

Lauren S. Hughes, MD, MPH Department of Family Medicine, University of Michigan NCRC Building 10, Rm G016-4A 2800 Plymouth Road

Ann Arbor, MI 48109-2800

1shughes@umich.edu

laurenshughes@gmail.com

\begin{abstract}
After witnessing a man commit suicide during my residency, I struggled to reconcile the trauma itself, my own competence, and multiple boundary issues I was exploring as a newly minted doctor. My powerlessness in the face of inevitability challenged my sense of capability to fulfill the very calling that brought me into medicine in the beginning - to help fix important problems in the lives of my patients. In the aftermath, I chose to remain connected to the experience in the way I honor him still today.
\end{abstract}

Ann Fam Med 2015;13:181-183. doi: 10.1370/afm.1759.

Swung into the parking lot and turned off the engine, letting the radio continue to play as a young man on the program shared how painful and scary his wife's diagnosis of bipolar disorder was-how high the highs could be, how low the lows. I sat alone for minutes, captivated. His wife attempted suicide multiple times throughout their marriage. "I got to the point where I could hide her pills ... and anything else she could think of to harm herself. But, I - I couldn't hide the bridges."

Bridges, I thought. Seattle bas lots of bridges. You can't bide those.

And in an instant, I was right back there, on that bridge.

While stopped at the red light, I quickly checked my beeping pager. I was already a few minutes late and feeling antsy. I didn't like running behind, but Seattle family medicine residency meant training in many placessometimes 2 or even 3 locations daily. Negotiating urban traffic snarls was part of the deal, and the drizzle that day certainly didn't help matters.

The beeps were what I feared: 2 admissions awaited me in the emergency department. As I clicked through the brief text messages, the man behind me honked, alerting me to the green light. I shoved the pager back in its holder and turned left onto the I-5 southbound ramp.

I merged on the interstate as I had done countless times before, staying in the right lane. I loved this aerial view of my Emerald City: the Space Needle presided over Lake Union houseboats on my right; crew teams cut through Portage Bay on my left; snow-capped mountains surrounded me on all sides. And even though I couldn't see it, my favorite seafood restaurant was tucked hundreds of feet below the bridge I now traversed.

As I passed the point where the bridge sharply arches over the streets below, a small, gray car stopped abruptly in front of me and flashed its hazard lights. My doctor's brain processed information rapidly, but my differential diagnosis yielded no answers. The lane ahead of the driver was clear $_{i}$ the roads weren't too wet yet, and the tires that I could see were still intact. I tapped my brakes, preparing to change lanes.

Very deliberately, the driver-a man in a plaid flannel shirt and jeansjumped out and slammed his door. He appeared to be in his mid-30s and was tall and thin. I leaned forward, peering through my dirty windshield to get a better look. I couldn't see his face.

In 3 brisk strides, he bounded from the driver's door around the hood of his car to the edge of the bridge. He grabbed the railing firmly with both hands and quickly climbed over. 
I went into medicine to help people, to shape their futures. But here-playing out in front of me-was a future I couldn't change. I frantically lowered my passenger window and yelled into the roar of the passing wind.

I wanted his confidence to falter, but it didn't.

He loosened his grip and disappeared from sight, melting from my view. In less than 5 seconds after stopping his car, he was gone.

I quickly brought my van to a halt. By this time, another man had stopped, too. I yelled at him to call 911 while I ran the few paces back to the man's car. I gripped the railing where he had just been and looked down. His body had come to rest hundreds of feet below, on the narrow ribbon of pavement curving along the water's edge. An older man and younger woman stood motionless by their truck parked haphazardly in the middle of the street below, horror-stricken at the scene in front of them.

I recoiled with nausea and pushed back from the railing. The bridge rattled underneath my feet as semitrucks rolled past. I overheard the conversation with 911 in between the whistling of passing cars: man ... bridge ... jumped ... dead.

Without thinking, I opened his passenger door. As a resident physician trained in emergency response, I was primed to take action, to identify next of kin. I saw his well-worn Starbucks mug and scattered gum wrappers in the console. Stacks of work files were crammed in the seat. A picture of children-laughing, hugging, happy - was attached to the strap of his briefcase.

I quickly glanced in the back seat, blinking hard Two car seats, several books, and colorful children's sippy cups were strewn about. Stale, broken Cheerios were ground in the crevices of the upholstery. I reached for the glove compartment and found his and his wife's car insurance proof.

"The police will be here shortly," the man said. I nodded. I stared out over Lake Union, numb and waiting.

When the policeman arrived, he shook our hands and gave us each a piece of paper, asking us to detail exactly what we had seen and how it happened. I remember his speech was measured and matter-of-fact, as if he had responded to this type of scene a number of times previously.

"... but before you start writing, tell me a little bit about what you saw," the officer said.

I recited the facts as if I had rehearsed them for morning rounds. "He was a mid-30s appearing man, tall and lean. He stopped suddenly, got out, and ran around the front of his car to the bridge, crawled over, and jumped. It probably took all of 5, 6 seconds for this to happen. Here's his name," I said, handing over the insurance card.
"Thank you," he said. "I appreciate you writing up that report. I'll be in my car when you're done."

I took several minutes to complete the form before handing it over. The officer took one look at me and asked, "You all right, doc?"

"I will be," was all I said. I wiped the bridge grease on my scrubs as I walked slowly back to my van and drove away, resuming my trek to the hospital and the admissions that awaited me.

For the following week or 2, I could think of little else and replayed the scene over and over in my mind. It was hard to focus in clinic. It took me a couple of weeks before I could drive over the I-5 bridge. But within the month, I stopped waking up in the middle of the night with a panicked feeling that I was the one falling, not him.

In some ways, I felt I had become a silent part of this family's narrative, not by choice but by circumstance. I was curious to know if he had sought help. Did his wife know he was contemplating his jump? Had he attempted suicide before? Maybe she had tried to hide his pills. I couldn't stop wondering how his family was coping. I hoped she had as strong a support system as I did in my friends, co-residents, and housemate.

In the beginning, I processed the trauma as anyone would, experiencing difficulty sleeping, startling easily, and feeling on edge. But after my initial symptoms quieted, I struggled for a long while in other areas because I didn't allow myself enough time to emotionally process what I had witnessed. At the time of his suicide, I was already in mental overload, learning how to supervise interns and keep pace with increasing volume in clinic as a new 2nd-year resident. My stress level was fairly high before I saw him jump, but afterward it spiked. I put a lot of pressure on myself to sift through my reactions as quickly as possible so that I could be emotionally available for my patients. The extra pressure only increased my stress and left me feeling slow and empty and withdrawn until time eventually eased those feelings.

This experience shaped me not only personally but also professionally. Throughout residency, I felt caught in the crossfire of exploring multiple professional boundaries, trying different ones on for size, figuring out the type of doctor I wanted to be. Was I supposed to be my patients' friend, teacher, or doctor? Or a combination of all 3? After his suicide, I encountered additional boundary questions. Was I always a doctor outside the office? In an emergency situation ... on a bridge? Moreover, my own evolving competence as a physician-in-training took a bit of a hit. My powerlessness in the face of his inevitable jump challenged my sense of capability to fulfill the very calling that brought me into medicine in the beginning - to 
help fix important problems in the lives of my patients. What did it mean that I couldn't fix his?

I am grateful that with ever-growing distance since that day, I no longer struggle professionally with the answer to another question that troubled me at the time: was this man my patient? At first, I most certainly felt that he was, for what I witnessed that day impacted me as intensely as some of my most meaningful doctor/patient relationships. A vast majority of my underserved patients in residency battled mental illness, many of whom harbored suicidal ideation or had attempted self-harm in the past. He could easily have been one of my own patients whose afflicted thoughts gave way to fateful actions beyond my control. And like my other patients who had died during residency, I wanted to process the experience with his family, to help them-and me-heal. I had attended funerals of my patients before. Was I supposed to go to his?

I turned to my clinical mentors and asked if it would be appropriate for me to send a note to his wife. After a lengthy conversation with one of them, she said, "I wouldn't. I understand why you want to, but, Lauren, he wasn't your patient." It took me a while to fully grasp her perspective. I wondered at first if her feelings about writing a note would have been different if I weren't a doctor. I puzzled over whether my physician boundaries trumped my more expansive human ones in need of connection and resolution.

In the end, I decided that I had a relationship to the situation and its aftermath but not to the man himself, despite the intensity of his final moment or my subsequent introspection. I have not forgotten him, however. I honor him every time I ask my patients about their mental well being ... openly, sincerely, routinely. I don't retreat from what I may not be able to influence. I choose to be fully human and present, open to the risks and rewards of accompanying my patients as they write their own narratives.

A few weeks after his suicide, I found myself running late after clinic to join friends for dinner. Without thinking, I intuitively chose the most direct route from the hospital to the pub, which led me along a park underneath the I-5 overpass. As my van emerged from under the bridge, a motion caught my eye. I slammed on my brakes in the middle of the intersection and peered upward. In the soft, yellow glow of the streetlight, I was relieved to see that the only thing falling was the soft Seattle rain.

To read or post commentaries in response to this article, see it online at http://www.annfammed.org/content/13/2/181.

Key words: suicide; trauma; professional boundaries

Submitted July 17, 2014; submitted, revised November 16, 2014; accepted December 10, 2014.

Acknowledgements: The author would like to thank Tammy Chang, MD, MPH, MSc; Justin List, MD, MAR, MSc; Donovan Maust, MD, MSc; Michelle Moniz, MD, MSc; and Renuka Tipirneni, MD, MSc, for critiquing drafts of this manuscript. The author would like to dedicate this essay to Rachel Faber Machacha, Daniel Ruegg, MD, and Jonathan Wells, MD. 